\title{
Clinical Evaluation of the Retention of Resin and Glass lonomer Sealants Applied as a Part of School-Based Caries Prevention Program
}

Asem Alkhodairi, Mohammad Alseweed, Sulaiman Alwashmi, Ramy A. Elmoazen

College of Dentistry, Qassim University, Quassim, Saudi Arabia

\author{
Citation: Alkhodairi A, Alseweed M, Alwashmi S \\ Elmoazen RA. Clinical Evaluation of the Retention of \\ School-Based Caries Prevention Progrim \\ Maced J Med Sci. 2019 Dec 15; 7(23):4127-4130. \\ https://doi.org/10.3889/oamjms.2019.869 \\ Keywords: Sealant; Dental sealant: Glass inomer \\ Resin; Resin sealant; Primary school; Caries prevention \\ *Correspondence: Sulaiman Alwashmi. College of \\ Dentistry, Qassim University, Quassim, Saudi Arabia. E- \\ Received: 30-Oct-2019; Revised: 24-Nov-2019; \\ Accepted: 25-Nov-2019; Online first: 13-Dec-2019 \\ Copyright: ๑) 2019 Asem Alkhodairi, Mohammad \\ Alseweed, Sulaiman Alwashmi, Ramy A. Elmoazen. This \\ is an open-access article distributed under the terms of \\ International License (CC BY-NC 4.0) \\ Funding: This research did not receive any financial \\ Competing Interests: The authors have declared that no \\ competing interests exis
}

\begin{abstract}
BACKGROUND: Using of sealant on pits and fissures is likely one of the most generally well-known strategies by the new cavity-prevention systems.

AIM: The purpose of this research is to measure the retentiveness of sealants of resin-modified ionomer glass cement $(\mathrm{GIC})$ and resin pits and fissures, on the first permanent molars of special patients as a part of caries prevention program in schools.

METHODS: The sample was comprised by 60 molars. Resin-based sealants on one side and glass-ionome sealant on the contralateral side of the mouth. The molars were examined in three and six months after application for retention with three standards: TR: Totally Retained; PR: Partially Retained; and CL: Completely Lost.

RESULTS: by the end of the study $60 \%$ of resin sealant was present. While $55 \%$ of GIC were retentive after 6 months.

CONCLUSION: Resin sealants are more retentive than glass ionomer sealants in school-based carries prevention program.
\end{abstract}

\section{Introduction}

Worldwide, public oral health struggled to be progressed by dental experts. School-based programs have been founded to supply anticipation administration, including oral health for school-aged children [1], [2]. These programs advantage lowercost care to a wide group of children, particularly people who are less likely to receive dental care due to financial confinements and restricted fluoride exposure [2].

Utilizing the schools to prepare oral health advancement mediation was suggested by the World Health Organization (WHO) in 2002.

Administered tooth brushing, oral health education/promotion, fluoride and fissure sealant application, and/or different treatments are activities included in school programs [3], [4].

These activities can constitute children's health-related convictions, demeanor, behaviors, and values. Also, prove proposes that a healthy life of adulthood can be impacted by oral health administrations [3], [4]. Even though school-based oral health instructions are viable in enhance oral health information and advancing oral hygiene and practices [5], [6], there could be an inquire about crevice within the writing on the effect of multiapproach preventive programs [1].

One of the most effective methods to prevent dental decay is using dental sealants [7]. They can be applied in private clinics, or as a part of school-based programs [8]. Community-based dental programs in schools are most regularly supported with public funds in non-profit organizations, and in some cases by 
educational foundations. the main objective of schoolbased dental programs are serving children with higher risk, counting children who less likely to receive private dental care [9], [10].

Dental caries is a preventable infection which might be stopped in the initial phases with pits and fissure sealants in permanent posterior teeth. There are mainly two sealant materials used to seal pits and fissure: glass ionomer sealant and resin-based sealant. the resin-based sealant is the most common material used to seal pits and fissure. Resin-based sealants change the morphology of the occlusion by creating a micromechanical-bonded layer which acts as a barrier between the oral environment and the occlusal surface. While resin-based sealant will be retained more than GIC, GIC has an advantage over the resin-based sealant that it can be applied on nonitched surface, Also GIC has a continues release of fluoride from the cement. However, it is uncertain of which sealing material type provide better caries prevention [11].

One of the major disadvantages of sealing with resins is the sensitive application to prevent moisture contamination, especially in molars which are partially erupted. On the other hand, GIC is less sensitive to moisture which makes it less sensitive and more favorable in some situations where teeth isolation is difficult and in partially erupted teeth [12]. The purpose of this research was to measure the retentiveness of sealants of resin-modified ionomer glass and resin pits and fissures, on special patients with first permanent molar as a part of school-based prevention program of caries.

\section{Materials and Methods}

\section{Data Collection}

Following approval of Community dentistry department and ethical committee at college of dentistry, Qassim university, approval forms with survey questions were delivered home with the students of first grade to be accomplished and gave back one week before examination. In addition to demographic data questions about the children and approval for applying sealant at the school, several multiple-choice and oral health-related questions were included in the questionnaires, including, frequency of brushing teeth, how lately the children went to a dental clinic. With light source and disposable dental mirrors/ tongue depressors, trained dental interns at college of dentistry Qassim university directly examined children with one or more missing, decayed, or filled teeth (caries experience); dental sealants and decayed teeth (untreated caries). Explorers were obtainable but not frequently used and certainly not by force (Figure 1).

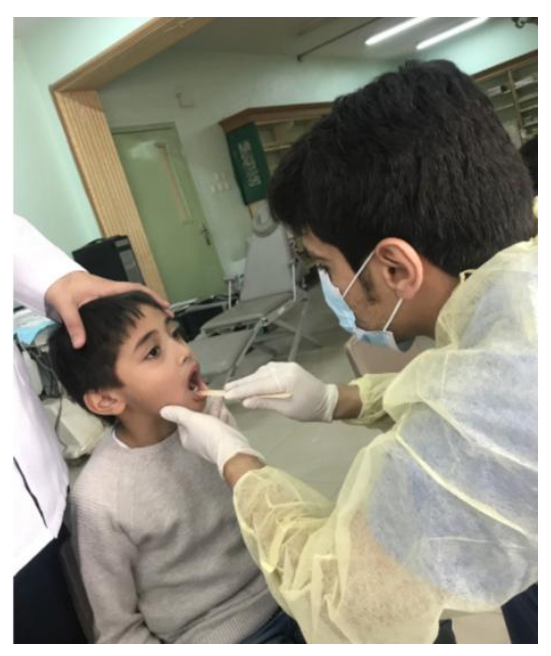

Figure 1: Examination of children

\section{Sampling}

A listing of schools with first grades were drawn for a stratified, clustered random sample in Buriydah, Qassim (mean age $7.84 \pm 0.73$ years). NonSaudi children were excluded from the study due to different socio-economic and food habits. Schools were stratified based upon Residential quarter. A complete of 18 schools have been chosen from among, and all students of first-grade were acceptable to be examined in every school. Only children with consent of parents were examined. The inclusion criteria included were, the existence of the four first permanent molars - totally erupted and with no cavitation, the absence of bruxism. The exclusion criteria included were, children with developmental anomalies and those with hypoplastic permanent first molars. The assessment, applying, and analyzing of the sealants were carried out between January 2018 to February 2019. The total sample size includes 30 students with 120 molar teeth.

\section{Sealants Application}

Split mouth design was the pattern selected to conduct this study. The procedure of sealing was done with partial isolation of the molars to be sealed by placing cotton rolls. A prophylaxis brush was used to clean the occlusal surfaces of molars that will be sealed. Resin-based sealant was used to seal two molars, using the preceding etching with phosphoric acid $35 \%$, for 30 seconds and then washed away by utilizing air-water spray. Using a brush or the needle tip of syringe, the sealant was slowly introduced into the pits and fissures. Finally, light cure unit was used to cure the sealant by exposing the sealant to light. Each surface requires light exposure of a 20 -second.

The other two molars were cleaned and dried then sealed using Powder liquid Glass ionomer. The application done in dry filed free of saliva, then left to be cured chemically. 


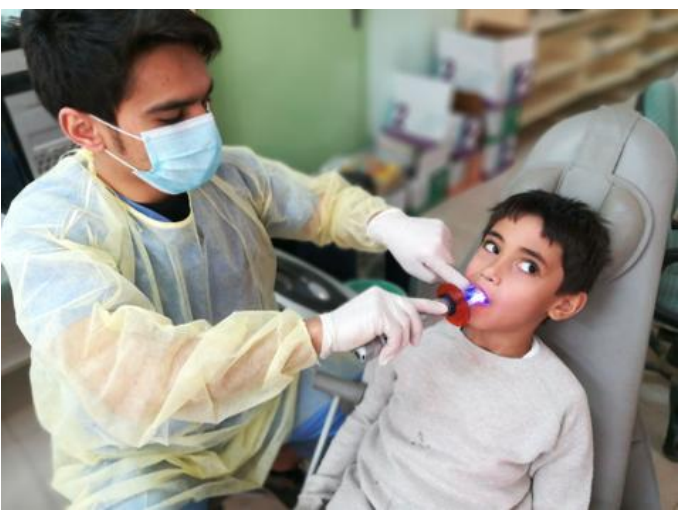

Figure 2: Light cure Resin Sealant Application

\section{Clinical Evaluation}

After 5 months of the placement of sealants, they were checked, 3 values were used to evaluate $P$ : Present; PP: Partially Present; and L: Lost. Lost sealants were not positioned once more through the research.

After 5 months we observed the retention of the two materials, the observation following 3 values: Present; Partially Present; Lost.

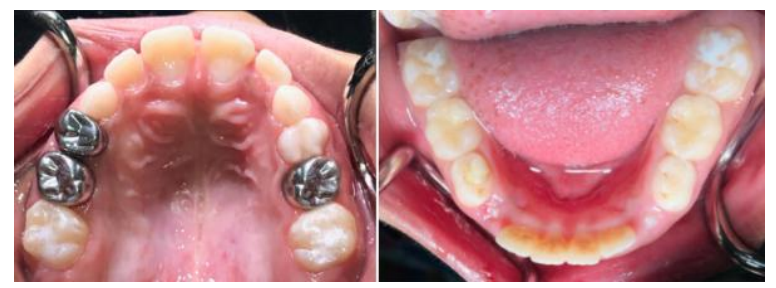

Figure 3: Sealant applied (Resin in Upper right and lower Left molars and Glass lonomer in Upper left and Lower right molars)

\section{Statistical Analysis}

Data was tabulated and analyzed using SPSS ver. 22 for windows. Retention of sealants presented in frequency and percentage. Comparison between the two study groups using Chi-Square test at significance level $p<0.05$.

\section{Results}

Among the total sample of 30 students, 120 first permanent molars teeth were sealed; 60 molars with resin sealant and 60 molars with glass ionomer sealant. Evaluation of retention after 3 months showed the majority of sealant present $(83.3 \%$ of resin sealant and $63.3 \%$ of GIC sealant) while $13.33 \%$ of GIC sealants were lost with no completely lost after 3 months of sealants application with statistical significant difference between the two groups $(p=$ 0.006) (Table1).
Table 1: Retention of Sealant after 3 months

\begin{tabular}{|c|c|c|c|c|c|c|c|}
\hline \multirow{3}{*}{ Retention } & \multicolumn{6}{|c|}{ Sealant } & \multirow{3}{*}{$\chi^{2}(p)$} \\
\hline & \multicolumn{2}{|c|}{$\begin{array}{c}\text { Resin } \\
\mathrm{N} 1=60\end{array}$} & \multicolumn{2}{|c|}{$\begin{array}{c}\text { GIC } \\
\text { N2 }=60\end{array}$} & \multicolumn{2}{|c|}{$\begin{array}{c}\text { Total } \\
N=120\end{array}$} & \\
\hline & No. & $\%$ & No & $\%$ & No & $\%$ & \\
\hline Present & 50 & $83.33 \%$ & 38 & $63.3 \%$ & 88 & $73.33 \%$ & \\
\hline $\begin{array}{l}\text { Partially } \\
\text { Present }\end{array}$ & 10 & $16.67 \%$ & 14 & $23.33 \%$ & 24 & $20.0 \%$ & 10.303 \\
\hline Lost & 0 & $0.0 \%$ & 8 & $13.33 \%$ & 8 & $6.67 \%$ & \\
\hline
\end{tabular}

On the Other hand (Table 2) showed $60 \%$ of resin sealants and $50 \%$ of GIC were still present after 6 months and the completely lost sealants were $3.33 \%$ in resin sealants and $33.33 \%$ of GIC sealants with highly statistical significant difference between the two groups $(p<0.001)$.

Table 2: Retention of Sealant after 6 months

\begin{tabular}{|c|c|c|c|c|c|c|c|}
\hline \multirow{3}{*}{ Retention } & \multicolumn{6}{|c|}{ Sealant } & \multirow{3}{*}{$\chi^{2}(p)$} \\
\hline & \multicolumn{2}{|c|}{$\begin{array}{c}\text { Resin } \\
\mathrm{N} 1=60\end{array}$} & \multicolumn{2}{|c|}{$\begin{array}{c}\text { GIC } \\
\mathrm{N} 2=60\end{array}$} & \multicolumn{2}{|c|}{$\begin{array}{c}\text { Total } \\
\mathrm{N}=120\end{array}$} & \\
\hline & No. & $\%$ & No & $\%$ & No & $\%$ & \\
\hline Present & 36 & $60 \%$ & 30 & $50 \%$ & 66 & $55 \%$ & \\
\hline $\begin{array}{l}\text { Partially } \\
\text { Present }\end{array}$ & 22 & $36.67 \%$ & 10 & $16.67 \%$ & 32 & $26.67 \%$ & $19.773(p$ \\
\hline Lost & 2 & $3.33 \%$ & 20 & $33.33 \%$ & 22 & $18.33 \%$ & \\
\hline
\end{tabular}

\section{Discussion}

A pit and fissure sealant is a resin material that is used to seal the pits and fissures of cariessusceptible teeth, by micromechanical bond, a physical layer used to protect and prevent. the demineralization of enamel by Blocking cariogenic bacteria's contact with their nutrient substrates, so removing the harmful acidic products [10]. prevention is the main cause of using sealant. the anatomy of pit and fissure in children is more susceptible of caries, so the occlusal caries is frequent in children, so in this research, we concentrate on primary school children as their first permanent molar has erupted [13].

This research aims to compare the retention between the glass ionomer sealant and the resinbased sealant in permanent first molars of primary school children. In this study, after 3 months the retention of resin-based sealant results was $83.33 \%$ completely present, $16.67 \%$ partially present and, no complete loss of resin. Whereas the retention of glass ionomer sealant was $63.33 \%$ completely present, $23.3 \%$ partially present and, $13.33 \%$ complete loss of glass ionomer sealant. After 6 months the retention of resin-based sealant results were $60 \%$ completely present, $36.67 \%$ partially present and, $3.33 \%$ complete loss of resin. Whereas the retention of glass ionomer sealant was $50 \%$ completely present, $16.67 \%$ partially present and, $33.33 \%$ complete loss of glass ionomer sealant. Mariana et al., [14] performed a study where they compared resin and glass ionomer sealants retention and revealed that after 6 months period resin-based sealants revealed $53.12 \%$ complete presence of resin sealant, partial presence of $18.75 \%$, and $28.12 \%$ were completely lost. While 
glass ionomer sealants in this study show that the complete presence of sealant was $53.12 \%$, the partial presence was $9.37 \%$ and the complete absence of sealant was $37.5 \%$. Subramaniam P1 et al., [15] study showed resin-based sealant retention after 6 months as $38.3 \%$ completely retained, $50.5 \%$ partially retained, and $11.2 \%$ missing. Whereas glass ionomer: $13.1 \%$ completely retained, $49 \%$ partially retained, and $37.9 \%$ missing.

Ulusu et al., [11] study revealed after 6 months period resin-based sealants were: $47 \%$ complete presence of resin sealant, partial presence of $40.3 \%$, and $11.9 \%$ were completely lost. While glass ionomer sealants in this study show that the complete presence of sealant was $45.7 \%$, the partial presence was $29 \%$ and the complete absence of sealant was $24.5 \%$.

In this study, after six months clinical evaluation confirmed the complete absence of caries in all teeth, although a lot of them had missing sealant. It is significant to take into consideration that the six-months follow-up period is a short time to assess the impact on new caries showing up. Guler et al., [16] found regardless of the sealant used, 3\% of the teeth treated caries were found. Kervanto et al., [17] compared the effect of caries inhibition on 2 types of sealants in a group of children between 12 and 16 years of age and found a statistically significant difference in caries inhibition as they considered resinbased sealants to be more efficacious than glass ionomer. Poulsen et al., [18] found teeth that were sealed with glass ionomer cement have more caries.

Possibly the causes for resin sealant lack of success might be the placement technique, operator skills, and tooth position inside the patient mouth. On the other side, the reasons for glass ionomer sealant failure can be insufficient adhesion to the enamel, isolation problems, and excessive salivation [15].

This study conclude that the glass ionomer sealant has less retention, but it requires less professional skills, so the application of glass ionomer is easier specially in the schools due to lack of isolation and prober equipment. Also, the retention of resin sealant is better than glass ionomer sealant, but its application demands very excellent isolation to meet the success of prober retention.

\section{References}

1. Cooper AM, O'Malley LA, Elison SN, Armstrong R, Burnside G, Adair $P$, et al. Primary school-based behavioural interventions for preventing caries. Cochrane Database Syst Rev. 2013; 31(5):CD009378. https://doi.org/10.1002/14651858.CD009378.pub2

2. Centers for Disease Control and Prevention. Promoting oral health: interventions for preventing dental caries, oral and pharyngeal cancers, and sports-related craniofacial injuries. A report on recommendations of the task force on community preventive services. MMWR Recomm reports Morb Mortal Wkly report Recomm reports. 2001; 50(RR-21):113

3. Alsumait A, EISalhy M, Amin M. Long-term effects of school-based oral health program on oral health knowledge and practices and oral health-related quality of life. Med Princ Pract. 2015; 24(4):362-8. https://doi.org/10.1159/000430096 PMid:26045154 PMCid:PMC5588237

4. Brownson RC, Haire-Joshu D, Luke DA. SHAPING THE CONTEXT OF HEALTH: A Review of Environmental and Policy Approaches in the Prevention of Chronic Diseases. Annu Rev Public Health. 2006; 27:341-70

https://doi.org/10.1146/annurev.publhealth.27.021405.102137

PMid:1653312

5. Worthington $\mathrm{H}$ V., Hill KB, Mooney J, Hamilton FA, Blinkhorn AS. A cluster randomized controlled trial of a dental health education program for 10-year-old children. J Public Health Dent. 2001; 61(1):22-7. https://doi.org/10.1111//.1752-7325.2001.tb03351.x PMid:11317600

6. Tai B, Du M, Peng B, Fan M, Bian Z. Experiences from a schoolbased oral health promotion programme in Wuhan city, PR China. Int $\mathrm{J}$ Paediatr Dent. 2001; 11(4):286-91. https://doi.org/10.1046/j.1365263X.2001.00281.x PMid:11570445

7. Beauchamp J, Caufield PW, Crall JJ, Donly K, Feigal R, Gooch B, et al. Evidence-Based Clinical Recommendations for the Use of Pit-andFissure Sealants. J Am Dent Assoc. 2008; 139(3):257-68. https://doi.org/10.14219/iada.archive.2008.0155 PMid:18310730

8. Naik SB, Patil SN, Kamble SD, Mowade T, Motghare P. Reliability of Third Molar Development for Age Estimation by Radiographic

Examination (Demirjian's Method). J Clin Diagn Res. 2014; 8(5):ZC258. https://doi.org/10.7860/JCDR/2014/8160.4361 PMid:24995239 PMCid:PMC4080060

9. Best Practice Approaches for School-based Dental Sealant Programs. Association of State \& Territorial Dental Directors, 2017:1 17.

10. Carter NL, Lowe EA. Seal America: The Prevention Invention. 3rd Ed. Washington, DC: The American Association for Community Denta Programs and the National Maternal and Child Oral Health Resource Center; 2016

11. Ulusu T, Odabaşv ME, Tüzüner T, Baygin Ö, Sillelioğlu $H$, Deveci $\mathrm{C}$, et al. The success rates of a glass ionomer cement and a resinbased fissure sealant placed by fifth-year undergraduate dental students. Eur Arch Paediatr Dent. 2012; 13(2):94-7. https://doi.org/10.1007/BF03262852 PMid:22449810

12. Clinical AC, American Academy of Pediatric Dentistry. Guideline on pediatric restorative dentistry. Pediatric dentistry. 2012; 34(5):173.

13. Kidd EAM, Smith BGN. Pickard's Manual of Operative Dentistry. 8th Ed. Oxford And IBH Publishing Co; 2004

14. Morales-Chávez MC, Nualart-Grollmus ZC. Retention of a resinbased sealant and a glass ionomer used as a fissure sealant in children with special needs. J Clin Exp Dent. 2014; 6(5):e551-5. https://doi.org/10.4317/jced.51688 PMid:25674325 PMCid:PMC4312685

15. Subramaniam $P$, Konde $S$, Mandanna D. Retention of a resin-based sealant and a glass ionomer used as a fissure sealant: A comparative clinical study. J Indian Soc Pedod Prev Dent. 2008; 26(3):114-20. https://doi.org/10.4103/0970-4388.43192 PMid:18923223

16. Guler C, Yilmaz Y. A two-year clinical evaluation of glass ionomer and ormocer based fissure sealants. J Clin Pediatr Dent. 2013; 37(3):263-7. https://doi.org/10.17796/jcpd.37.3.38761 uwwm7kpj616 PMid:23855170

17. Kervanto-Seppälä S, Lavonius E, Pietilä I, Pitkäniemi J, Meurman $\mathrm{JH}$, Kerosuo E. Comparing the caries-preventive effect of two fissure sealing modalities in public health care: A single application of glass ionomer and a routine resin-based sealant programme. A randomized split-mouth clinical trial. Int J Paediatr Dent. 2008; 18(1):56-61. https://doi.org/10.1111/i.1365-263X.2007.00855.x PMid:18086027

18. Poulsen S, Beiruti N, Sadat N. A comparison of retention and the effect on caries of fissure sealing with a glass-ionomer and a resinbased sealant. Community Dent Oral Epidemiol. 2001; 29(4):298-301. https://doi.org/10.1034/i.1600-0528.2001.290409.x PMid:11515644 